\title{
Replication of infectious Pancreatic Necrosis Virus in different cell lines and in rainbow trout (Oncorhynchus mykiss) fingerlings
}

\author{
Natalija Matvienko, Yury Rud, Leonid Buchatsky
}

Received - 25 June 2013/Accepted - 27 February 2014. Published online: 30 June 2014; @Inland Fisheries Institute in Olsztyn, Poland Citation: Matvienko N., Rud Y., Buchatsky L. 2014 - Replication of infectious Pancreatic Necrosis Virus in different cell lines and in rainbow trout (Oncorhynchus mykiss) fingerlings - Arch. Pol. Fish. 22: 127-133.

\begin{abstract}
The results of a study of Infectious Pancreatic Necrosis Virus (IPNV) isolated in natural reservoirs in Ukraine are presented. The pathogenicity of isolates was investigated in vitro on cell cultures and in vivo on rainbow trout, Oncorhynchus mykiss (Walbaum), fingerlings. Experimental indications were that the Ukrainian IPNV isolates have affinity with reference European strains. During the reproduction of these isolates in cell cultures of FHM (fat head minnow), RTG-2 (rainbow trout gonads), and BF-2 (bluegill caudal peduncle), complicated degenerative changes were visible that finally led to the full destruction of cell monolayers. The experimental infection of rainbow trout fingerlings resulted in typical disease symptoms that were systemic. However, obvious evidence of viral infection was noted in single individuals only, and the majority of experimental fish died without visible disease symptoms. During the study of physicochemical properties, it was noted that Ukrainian isolates completely lost their infectivity with chloroform treatment and heating to $60^{\circ} \mathrm{C}$. This proved that IPNV isolates are resistant to Ion concentrations in the range of pH 3.0 to 12.0 .
\end{abstract}

Keywords: cell culture, cytopathogenic effect, Infectious Pancreatic Necrosis Virus (IPNV), rainbow trout

N. Matvienko [@], Y. Rud, L. Buchatsky

Institute of Fisheries of the National Academy of

Agrarian Sciences of Ukraine,

135 Obukhivska Street, 03164 Kyiv, Ukraine

e-mail: mnarine73@mail.ru

\section{Introduction}

Aquatic birnaviruses (Aquabirnavirus family) comprise the largest viral group causing diseases in many fish and invertebrate species. Symptoms of these diseases were first described in freshwater trout in Northern America in the 1950s (Wood et al. 1955), and they have been noted in Europe since the 1970s (Ball et al. 1971). IPNV was first isolated in 1975 in Norway (Ahne and Negele 1985). To date, this virus has been isolated in Northern and Central America, Europe, and Southeast Asia (Bootland et al. 1991). The virus causes epizootics with high mortality rates in salmonid fry during farming production. Atlantic salmon, Salmo salar L., is the most susceptible species to this virus in marine waters with mortality rates of $70 \%$ or higher (Dorson 1985), while rainbow trout, Oncorhynchus mykiss (Walbaum), and brook trout, Salvelinus fontinalis (Mitchill), are the most susceptible species to this virus in freshwater aquaculture (Jorgensen 1969, Dorson 1985). Since the initiation of intensive trout breeding in Ukraine, the occurrence of infectious diseases among salmonids has not been adequately investigated. During a monitoring study conducted at the laboratory of fish pathology at the Institute of Fisheries of the National Academy of Agrarian Sciences of Ukraine (IF NAASU), the virus was isolated in trout fry in which outbreaks of IPNV had been diagnosed (Osadchaya 1984, Matvienko et 
al. 2011). The virus was probably introduced to Ukraine with impregnated roe imported from western European fish farms.

The aim of this study was to investigate the reproduction of Ukrainian isolates of IPNV in vitro in cell cultures and in vivo in rainbow trout fingerlings.

\section{Materials and methods}

\section{Fish}

Rainbow trout fingerlings were bred in the experimental aquarium room of the Institute of Fisheries of the National Academy of Agrarian Sciences of Ukraine. The fish were tested for parasitic, bacterial, and viral infections, and they were determined to be in good condition (Golovina and Bauer 2007).

\section{IPNV strains}

The following strains of IPNV were used in the study: reference strain $\mathrm{Ab}\left(8.0 \mathrm{lg} \mathrm{TCID}_{50} \mathrm{ml}^{-1}\right)$; Russian isolates of B09O m.f (8.5 lg TCID $\left.50 \mathrm{ml}^{-1}\right)$; SK07 m.f (7.5 lg TCID $50 \mathrm{ml}^{-1}$ ) obtained from VNIIPRH (Russian Federal Research Institute of Freshwater Fisheries). The material for the virological studies of the Ukranian IPNV isolates were collected at fish farms and natural water ponds in the western regions of Ukraine (Lviv, Transcarpathian region): VF-11 (6.8 lg TCID $50 \mathrm{ml}^{-1}$ ) and VF-08 (7.2 $\mathrm{lg}$ TCID $\left._{50} \mathrm{ml}^{-1}\right)$. These viruses were propagated in the fish pathology laboratory at the Institute of Fisheries of the National Academy of Agrarian Sciences of Ukraine.

\section{Cell culture}

Cell lines of FHM (fat head minnow) (Gravell and Malsberger 1965), RTG-2 (rainbow trout gonads) (Wolf and Quimby 1962), and BF-2 (bluegill caudal peduncle) (Wolf and Quimby 1971) were used for virus enrichment. Continuous fish cell cultures were cultivated according to guidelines by the authors for each of the lines.

\section{Mediums, solutions, and serums}

The mediums for cell growth were Eagles MEM, RPMI-16 with a double set of amino acids and vitamins, and DMEM/F12 (Sigma) with fetal bovine serum (FBS) and antibiotics (gentamycin, kanamycin, penicillin, ampicillin). A trypsin/EDTA solution (0.25/0.02\%), 1M Hepes-buffer ( $\mathrm{pH} 7.0)$, and $0.05 \%$ trypan blue solution were also applied.

\section{Virus preparation}

Pathologic material processing, virus isolation, experimental infection of trout, and virus infectivity evaluation were done according to procedures in international normative documents (OIE 2003, Mahy 1988). Virus was isolated in kidney and liver homogenates from fish caught at farms where viral infection was suspected. The homogenates were prepared with Eagles MEM transport medium (buffer system - 0.1 M Tris-HCl, $\mathrm{pH}$ 7.6) at a ratio of 1:5. The virus OR titer was determined with the statistic computation method and expressed in tissue culture infective doses of $1.0 \mathrm{ml}$ (TCID50 $\mathrm{ml}^{-1}$ ) (Reed and Muench 1938).

\section{Electron microscopy}

The morphology of the IPNV isolates was examined with a JM-100 electron microscope at an instrumental magnification of 30,000 and with negative staining.

\section{Effect of physical factors and chemical agents}

The effects of different factors and storage conditions on the virus were studied with standard virology methods (Mahy 1988) Samples of $5.0 \mathrm{ml}$ of cultured viral material clarified with centrifugation were 
poured into two test tubes to determine IPNV chloroform susceptibility, then $5.0 \mathrm{ml}$ of chloroform was added to one of the test tubes, and $5.0 \mathrm{ml}$ of chloroform was also added to the other tube of 5.0 ml-supported medium to monitor the toxic effect of chloroform on cell culture. All the test tubes were shaken for twenty minutes at room temperature, and then centrifuged for ten minutes at 2,000 g. Tenfold dilutions from supernatant were prepared and titrated in the cell culture. IPNV susceptibility to $\mathrm{pH}$ value was determined by preparing buffer solutions with hydrogen ion concentrations ranging from 3.0 to 12.0. Then $1.0 \mathrm{ml}$ of cell culture medium with viral material was added to test tubes - two for each $\mathrm{pH}$ value and two controls. All the tubes were kept at room temperature for thirty minutes, after which tenfold dilutions were prepared and titrated on cell culture. The impact of $\mathrm{pH}$ value on virus infectivity was determined by differences in virus infection titers before and after the treatment. Temperature inactivation and the destabilizing effect of magnesium ions were determined by virus infectivity before and after treatment in which $1.0 \mathrm{ml}$ of centrifuged cultural viral material was poured into three tubes, then $1.0 \mathrm{ml}$ of sterile, twice-distilled water was added to two tubes, and $1.0 \mathrm{ml}$ of sterile $\mathrm{MgCl}_{2}$ solution prepared with twice-distilled water was added to the third. The first tube was refrigerated at $4^{\circ} \mathrm{C}$, while the second and third were placed in a water bath for one hour at $60^{\circ} \mathrm{C}$. All three tubes were diluted at a 1:10 ratio with medium and titrated in cell cultures.

\section{Virus purification}

Virus isolates obtained from different cell lines were centrifuged and concentrated in polyethylene glycol according to the Kangro method (Mahy and Kangro 1996).

\section{Experimental infection}

Rainbow trout (O. mykiss) fingerlings, bred in the aquarium room at IF NAASU were used for experimental infection, which was performed in a separate laboratory in $40 \mathrm{l}$ tanks at $12^{\circ} \mathrm{C}$. Three groups of trout fingerlings - two experimental and one control, comprised ten specimens each with body weights not exceeding $15 \mathrm{~g}$. After preliminary adaptation, the fish were infected with IPNV through intraperitoneal injection. The virus used was culture fluid from IPNV infected RTG-2 cells that exhibited definite symptoms of (75 to $100 \%$ monolayer lesions and not lower than $10^{6} \mathrm{TCID}_{50} \mathrm{ml}^{-1}$ ). The amount of inoculum administered was $0.1 \mathrm{ml}$ per fish. Media from uninfected cell culture was used as the control in the same quantity of $1 \mathrm{ml}$ per fish. Clinical symptoms, pathomorphological changes, and fish mortality were observed throughout the development of the disease.

\section{Results}

The optimum temperature range for viral replication in the RTG-2, FHM, and BF-2 cell lines during the study of IPNV reproduction was $15-18^{\circ} \mathrm{C}$. The first morphological changes were observed within 24 hours following inoculation. IPNV induced complex degenerative changes indicated by the appearance of vacuoles and granulation. Infected cells became round, which ultimately led to the complete destruction of the monolayer (Fig. 1). Monolayer destruction was observed from three to four days post inoculation (d.p.i) during subsequent virus passages, while the infection titer increased by 0.3-0.5 lg in comparison with first viral passage. The experiment results are summarized in Table 1.

The pathogenicity of the isolated IPNV strains was determined by experimentally infecting trout fingerlings; IPNV isolates from Ukraine and Russia were used for comparison. The incubation periods of the different isolates differed little under the experimental conditions at water temperatures of $10^{\circ} \mathrm{C}$, and the incubation periods for isolates VF-8 and VF-11 were three and seven days, respectively. Symptoms of infection developed three to 12 d.p.i. reaching a peak on days 20 to 25 d.p.i when fingerling mortality was $38 \% \pm 0.9$ for SK07 and 


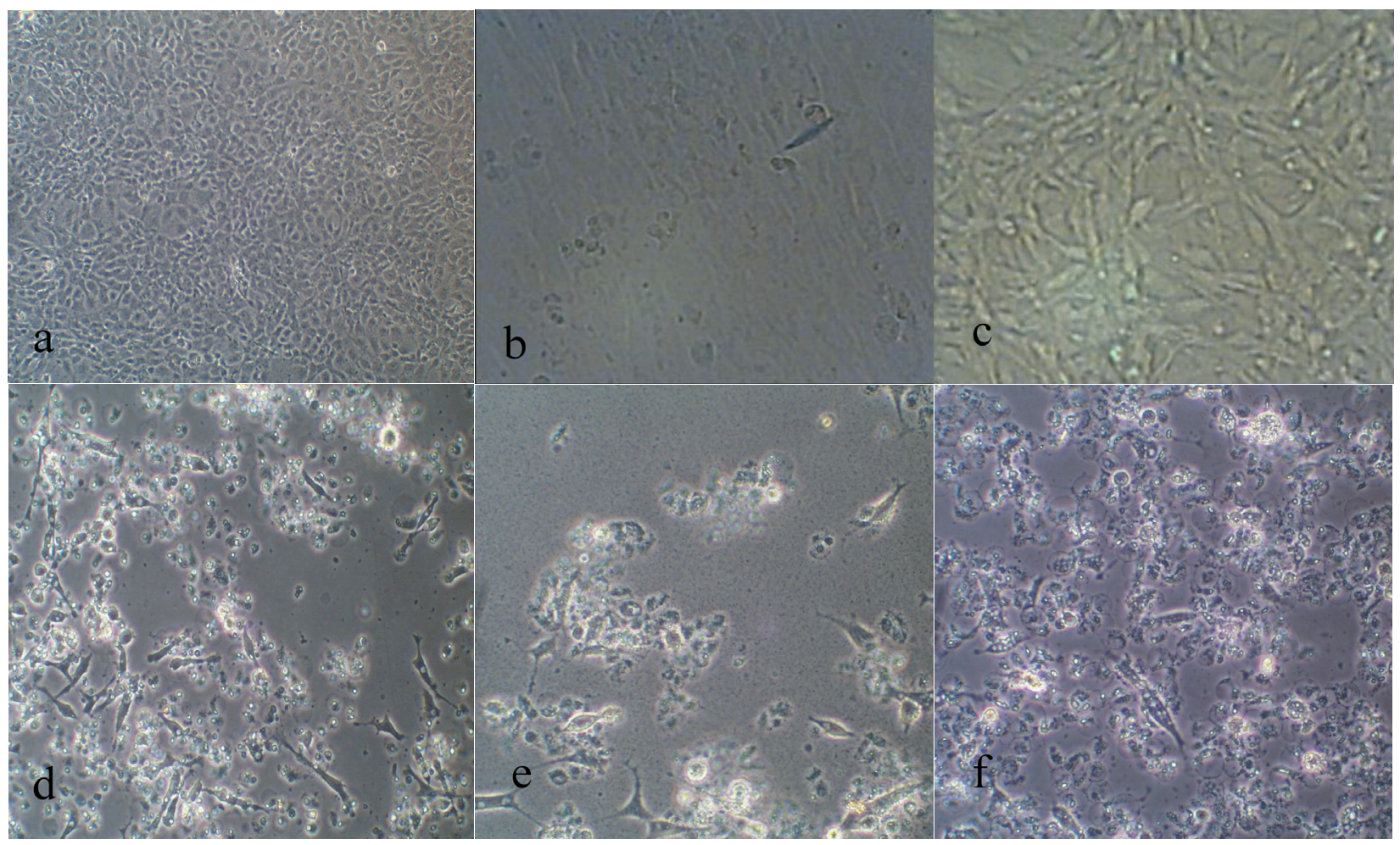

Figure 1. Changes of rainbow trout (O. mykiss) cell monolayer under IPNV infection. Non-infected cells of FHM (a), RTG-2 (b), BF-2 (c), and cell cultures of FHM (d), RTG-2 (e), BF-2 (f) infected with Ukrainian strain VF-11 (5 d.p.i., virus titre 7.2 lg TCID ${ }_{50} \mathrm{ml}^{-1}$ ).

Table 1

Infectious titer of Infectious Pancreatic Necrosis Virus in cell cultures. Cell culture: RTG - rainbow trout gonads, FHM - fat head minnow, BF-2 - bluegill caudal peduncle

\begin{tabular}{llll}
\hline & & \multicolumn{2}{l}{ Virus titer $\left(\lg \mathrm{TCID}_{50} \mathrm{ml}^{-1}\right)$} \\
\cline { 3 - 4 } Cell culture & Virus strain & I passage & II passage \\
\hline \hline RTG & Ab & 8.0 & 8.5 \\
& VF-11 & 6.8 & 7.5 \\
& VF-08 & 7.2 & 7.5 \\
& BO90 & 8.0 & 8.5 \\
& SK07 & 7.0 & 7.5 \\
FHM & Ab & 8.0 & 8.0 \\
& VF-11 & 6.8 & 6.8 \\
& VF-08 & 7.2 & 7.4 \\
& BO90 & 8.0 & 8.3 \\
& SK07 & 7.0 & 7.2 \\
BF-2 & Ab & 8.0 & 8.0 \\
& VF-11 & 6.8 & 7.0 \\
& VF-08 & 7.2 & 7.5 \\
& BO90 & 8.0 & 8.0 \\
& SK07 & 7.0 & 7.2 \\
\hline \hline
\end{tabular}




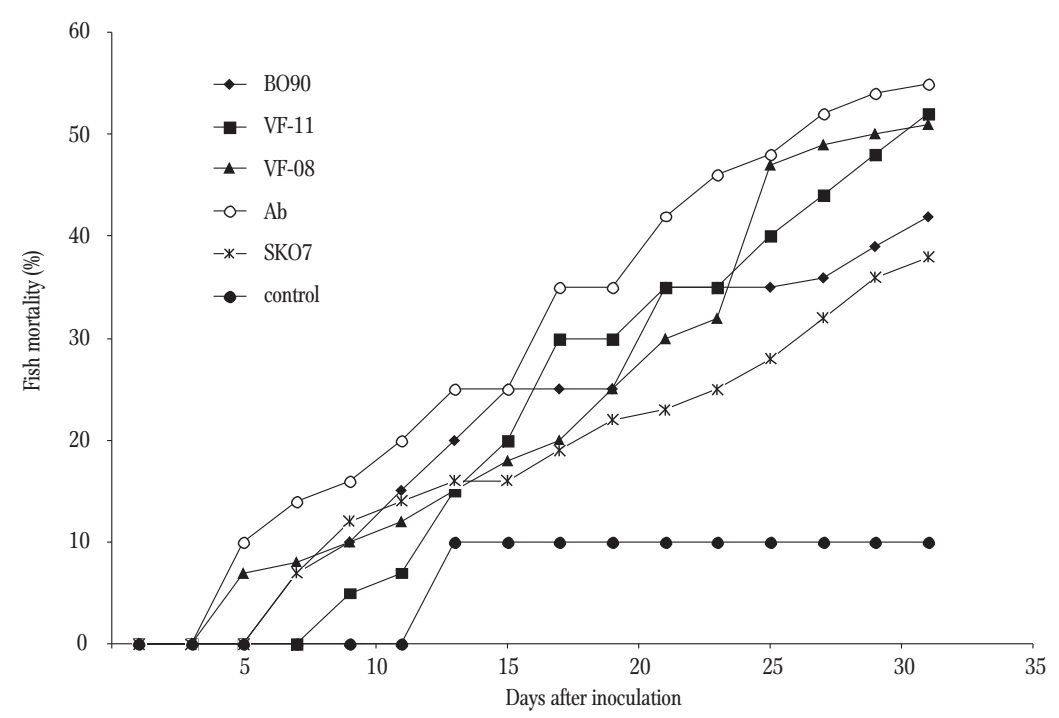

Figure 2. Mortality of rainbow trout (O. mykiss) fingerlings from experimental infection by different IPNV isolates.

$42-52 \% \pm 1.8$ for the BO90, VF-11, and VF-08 strains. The reference strain (Ab) was more aggressive, so fish mortality was the highest at $55 \% \pm$ 1.3 on 31 d.p.i. (Fig. 2).

Visual symptoms of progressing infection included skin darkening, disordered locomotion, and exophthalmos, which manifested in the fish making circular movements in one location. Acute infection was systemic, and the developed septic process caused lesions in almost all organs and tissues. Secretory cell necrosis and liver, kidney, and digestive tract lesions were noted. Clinical symptoms of disease included muscle lesions, gill edema, internal organ deformation, and tissue necrosis. All of these changes led to abnormalities in the water-mineral balance and fish mortality. The virus was isolated from the liver, kidney, gonads, digestive tract, and brains of fingerlings that exhibited no symptoms of disease. The study of the physicochemical properties of the isolated strains of IPNV indicated that heating to $60^{\circ} \mathrm{C}$ fully inactivated the virus in 15 minutes, and that the virus lost its infectivity at $\mathrm{pH} 3.0$ and 12 after 120 and 10 minutes, respectively. The virus is also susceptible to chloroform, but it is resistant to cold temperatures, and can be preserved in organs and tissues for two years at $-20^{\circ} \mathrm{C}$. Hexagonal and round virions from 65 to $85 \mathrm{~nm}$ in diameter were noted when samples were viewed with an electron microscope (Fig. 3).

\section{Discussion}

Several challenges face developing salmonid aquaculture in Ukraine, and one of these is infectious pancreatic necrosis. To date, the distribution and origin of IPNV in Ukrainian natural and fish-farming ponds has not been investigated sufficiently. Data from monitoring studies conducted routinely by the staff of the fish diseases laboratory at IF NAAS indicate there have been localized outbreaks of IPNV in trout fingerlings in Ukrainian fish-farming. Because trout aquaculture comprises the entire production cycle from spawning to market-sized fish, IPNV has a dramatic impact on salmonid rearing in Ukraine. IPNV was isolated in Ukraine in 2010 (Matvienko et al. 2011), and the probable vector of infection into Ukraine was and is the import of gametes for spawning from trout farms in neighboring countries. To date, IPNV has been

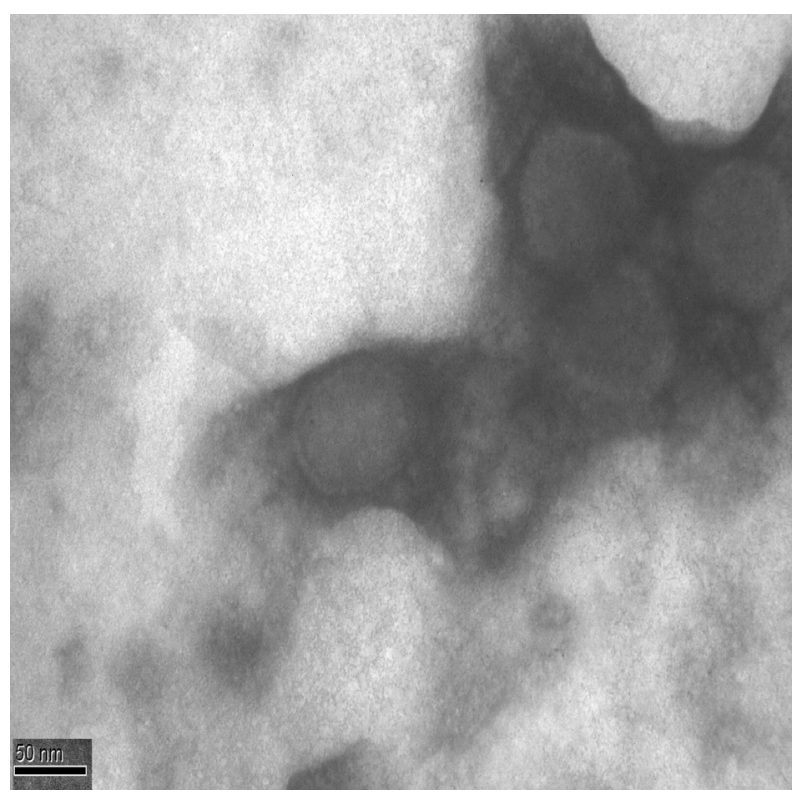

Figure 3. Electron microscope investigation of rainbow trout $(O$. mykiss) birnavirus, isolated in Ukraine (Uranyl acetate staining; magnification $\times 30,000)$. 
isolated in European, Southeast Asian, and North and Central American countries (Dixon et al. 2008). The present study indicates that the IPNV strains isolated experimentally in Ukraine have affinity with European reference strains. Virus propagation in FHM, RTG-2, and BF-2 cell cultures revealed hard, degenerative changes in cell morphology and generally in the monolayer, and the CPE of infected cells was also obvious. Morphological changes in cells ultimately led to the full destruction of the monolayer, and these types of change in tissue cultures have been reported by several researchers (Gravell and Malsberger 1965, Dorson 1985, Golovina and Bauer 2007). Alonso et al. (2004) used three cell lines - BF-2 (bluegill fry), EPC (epithelioma papulosum cyprinid), and CHSE-214 (chinook salmon embryo), to isolate IPNV from Senegalese sole, Solea senegalensis Kaup. The sensitivity of these cell lines to the virus was compared during an immunofluorescent assay (IFA), and the results indicated that IFA is the most suitable method for visualizing changes in the morphology and monolayer of IPNV-infected cells.

Under experimental infection conditions, IPN disease is systemic, and typical disease symptoms were noted in rainbow trout fingerlings. Internal organ lesions caused by the virus resulted in fish deaths; however; obvious symptoms of the viral infection were only noted in single individuals, and the majority of the fish in the experiment died without visible signs of disease. Systemic lesions of the internal organs in IPNV-infected fish have been reported by Golovina and Bauer (2007). Bootland et al. (1991) showed that IPNV can cause outbreaks among farmed juvenile salmon with mortality rates of $70 \%$. Ukrainian isolates of IPNV caused trout fingerling mortality as high as $55 \%$. Mortality rates associated with disease outbreaks can be quite variable (5-100\%), and various host, viral, and environmental factors affect the severity of outbreaks (Sano et al. 1992). While some host (e.g., nutritional status) and environmental factors (e.g., water quality) can be controlled, little is known about other viral virulence factors (Santi et al. 2005, Davies et al. 2010). The physicochemical properties of the isolates were also studied. The isolates completely lost their infectious activity when the chloroform treatment and heating to $60^{\circ} \mathrm{C}$ were applied. It was also demonstrated that isolates are resistant to medium influence within the range of 3.0 to $12.0 \mathrm{pH}$. The physicochemical characteristics indicated that the properties of the IPNV strains isolated in Ukraine are similar to those of the reference strains. Elucidating the adaptation mechanisms of fish to disease and defining health and pathology are important scientific aspects of modern aquaculture (Matvienko et al. 2011). The present article provides information about pathological changes in the organs and tissues of rainbow trout under the influence of infectious pancreatic necrosis virus. Pathological changes in liver tissues of experimentally infected rainbow trout were ascertained through histological analyses. These changes indicated that the liver is the first organ affected by IPNV. Hexagonal and round virions with diameters of $65-85 \mathrm{~nm}$ were noted during the electron microscope study of samples from experimentally infected trout. The results of our research are of theoretical value, but they also help to develop an understanding of the mechanisms of virus-host interaction, and can be used for developing practical methods for the prevention of disease and localizing the origin of viruses that pose significant risks to aquaculture in Ukraine and neighboring countries.

Author contributions. L.B. designed the concept and scheme of the experiments, N.M performed the experiments and analyzed the data, Yu.R. interpreted the data and wrote the paper.

Acknowledgments. This research was supported by the State Agency of Fisheries of Ukraine and the National Academy of Agrarian Sciences of Ukraine (Project No.0111U006973). The authors are grateful to Prof. Sven Bergman (Germany) for his help of providing fish cell lines. 


\section{References}

Ahne W., Negele R.D. 1985 - Studies on the transmission of infectious pancreatic necrosis virus via eyed eggs and sexual products of salmonid fish - In: Fish and Shellfish Pathology (Ed.) A.E. Ellis, Academic Press, London: 262-270.

Alonso M.C., Cano I., Castro D., Perez-Prieto S.I., Borrego J.J. 2004 - Development of an in situ hybridization procedure for the detection of sole aquabirnavirus in infected fish cell cultures - J. Virol. Methods 116:133-138.

Ball H.J., Munro A.L.S., Ellia A., Elson K.G.R., Hodgkiss W., Farlane L.S. 1971 - Infectious pancreatic necrosis in rainbow trout in Scotland - Nature 234: 417-418.

Bootland L.M., Dobos P., Stevenson R.M. 1991 - The IPNV carrier state and demonstration of vertical transmission in experimentally infected brook trout - Dis. Aquat. Org. 10: $13-21$.

Davies K.R., McColl K.A., Wang L.F., Yu M., Williams L.M., Crane M.St.J. 2010 - Molecular characterisation of Australasian isolates of aquabirnavirus - Dis. Aquat. Org. 93: 1-15.

Dixon P.F., Ngoh G.H., Stone D.M., Chang S.F., Way K., Kueh S.L.F. 2008 - Proposal for a fourth aquabirnavirus serogroup - Arch. Virol. 153:1937-1941.

Dorson M. 1985 - Experimental transmission of infectious pancreatic necrosis virus via the sexual products - In: Fish and Shellfish Pathology (Ed.) A.E. Ellis, Academic Press, London: 251-260.

Golovina N.A, Bauer O.N. 2007 - Ichthyopathology - Mir, Moscow, R448 p. (in Russian).

Gravell M., Malsberger R.G. 1965 - A permanent cell line from the fathead minnow (Pirnephales prornelas) - Ann. NY Acad. Sci. 126: 555-565.

Jorgensen P.E., Bregnballe F. 1969 - Infectious pancreatic necrosis in rainbow trout (Salmo gairdneri) in Denmark Nordisk Veterinaermedicin 21: 142-148.
Mahy B.W. 1988 - Virology a practical approach - Mir, Moscow, Russia, 344p.

Mahy B.W., Kangro H.O.1996 - Virology Methods Manual London, Academic Press, UK, 452 p.

Matvienko N., Buchatsky L., Deryabin O. 2011 - Isolation of IPN virus from rainbow trout in the Ukraine - 15th International Conference on Diseases of Fish and Shellfish, Split, Croatia, 12-16.09.11, Abstract book: 363.

OIE 2003 - Manual of diagnostic tests for aquatic animals Fourth Edition, Paris, Office International Des Epizooties.

Osadchaya E.F. 1984 - Developing ichthyovirusology in the USSR and abroad - In: Biological foundations of fish farming: parasites and fish diseases (Eds) O.N. Bauer, V.A. Muselius, E.S. Scriabin, Moscow: 28-46 (in Russian).

Reed L., Muench H. 1938 - A simple method of estimating fifty per cent endpoints - Am. J. Hyg. 27: 493-497.

Santi N., Sandtro A., Sindre H., Song H., Hong J.R., Thu B., Wu J.L., Vakharia V.N., Evensen O. 2005 - Infectious pancreatic necrosis virus induces apoptosis in vitro and in vivo independent of VP5 expression - Virology 342: 13-25.

Sano M., Okamoto N., Fukuda H., Saneyoshi M., Sano T. 1992 - Virulence of infectious pancreatic necrosis virus is associated with the larger RNA segment (RNA segment A) - J. Fish Dis. 15: 283-293.

Wolf K.,Quimby M.C. 1962 - Established eurythermic line of fish cells in vitro - Science 135: 1065-1066.

Wolf K., Quimby M.C. 1971 - Salmonid viruses: Infectious pancreatic necrosis virus morphology, pathology, and serology of first European isolations - Arch. Gesamte Virus-Forsch. 34: 144-156.

Wood E.M., Snieszko S.F., Yasutake W.T. 1955 - Infectious pancreatic necrosis of brook trout - AMA Arch. Pathol. 60: 26-38.

Zhang C.X., Suzuki S. 2004 - Aquabirnaviruses isolated from marine organisms form a distinct genogroup from other aquabirnaviruses - J. Fish Dis. 27:633-643. 